\title{
Rethinking Polanyi's Fictitious Commodities Based on the Brazilian Nuclear Segment
}

\section{Márcio Moutinho Abdalla*}

\begin{abstract}
The purpose of this paper is to show evidence of the undetermined expansion of Polanyi's fictitious commodities within the Brazilian nuclear context. The issue of the marketification of social agendas has drawn a lot of attention to the data, collected through in-depth interviews. The analytical process was guided by the decolonial theory approach and by critical discourse analysis. Among the analysis' main findings, it is possible to point out the elaboration of a framework which reveals the mechanisms employed by the Brazilian nuclear segment as a way of exercising parallel power and silencing social agendas. The main contributions are the temporal and geopolitical updating of Polanyi's thesis; and the definition of the mechanisms used by the company Eletronuclear and by institutions as a way of co-optation, naturalisation and marketification of social and political agendas.
\end{abstract}

Keywords: Karl Polanyi; fictitious commodities; nuclear; neoliberalism; decoloniality; critical discourse analysis; social agendas.

\section{Introduction}

The upward path followed by economic liberalism has brought about important debates that should at least be a warning sign to contemporary societies. The 'seductive' idea of self-regulation and freedom of the market has been strongly opposed by some theorists (including Karl Polanyi, Antonio Gramsci, Giovanni Arrighi, and Wolfgang Streeck) while fiercely defended by others, such as Ludwig von Mises, Frederich August von Hayek, and Milton Friedman, to cite a few. Throughout his life, Karl Polanyi was an ardent critic of the idea of a society guided by (and based on) a supposedly self-regulated market. His influential thoughts have been globally disseminated through his most inspirational labour - The Great Transformation.

Nevertheless, many economic segments have added strength to the neoliberal logic: some more evidently, others less so. With regard to the energy sector, one can argue that it has been systematically facing a series of problems, mainly due to the growing demand

* Federal Fluminense University (UFF), Volta Redonda-RJ, Brazil; marcioabdalla@id.uff.br. ORCiD 00000002-2607-1021. 
from (post)modern ${ }^{1}$ society. In Brazil, as in other countries considered as peripheral or semi-peripheral, the situation is no different, despite being asymmetrical with regard to its distribution and consumption between different classes (Abdalla 2014). The current global context, marked by intense technological transformations, helps to explain part of the problem of the expanding energy demand, as there has been an inversion of monetary values with regard to technological goods when compared to commodities, especially those related to sources of energy (Braga and Braga 2012). This inversion can be partly explained by the high competition process inherent to the neoliberal globalisation project, which allows for technological goods to become drastically cheaper - mainly at the cost of an undervalued labour force, exercised by workers in peripheral nations, in what can be seen as a new type of imperialism (Harvey 2005). This is one of the consequences of what Karl Polanyi called the market for fictitious goods, as he made reference to the incoherence present in the establishment of markets for land, money and labour (Polanyi 2012 [1945]).

Well, if goods can be characterised as elements produced for sale, then indeed, it is not possible to make a general classification of land, labour and money as goods. A priori, one may state that it would be somewhat risky to hand over to 'market forces' something which is inseparable from human beings - like labour, performed for a range of different purposes, not specifically for sale; or even the soil itself - the natural habitat of the human species or, interpreted in a simpler way, another name for nature itself. As for money, it is nothing more than just a believed-in symbol, referring to purchasing power, which exists through financial institutions, albeit originally invented as a way of encouraging trade by replacing barter (Frerichs 2013; Hart 1986; Polanyi 2012 [1945]). Even though money, land and labour are not goods strictly speaking, these are all essential elements within processes of industrialisation and are, therefore, organised into markets (Polanyi 2001 [1945]; Kischener et al 2015). However, the problem is aggravated when these fictitious commodities begin to be (self-) regulated by the market itself, hence leading societies to processes of degradation and to what Polanyi has called the Satanic Mill.

Polanyi looked forward to a social turnaround that could de-articulate liberal problems related to market orientation and thus envisaged beneficial consequences arising from this logic (Dale 2013; Levitt 2013; Munck 2004; Polanyi 2012 [1945]). However, in spite of the deep crises of neoliberalism (Arrighi 1994; Polanyi 2012 [1945]; Streeck 2016), Polanyi did not foresee the proliferation of fictitious commodities, especially those nurtured by processes of domination and geopolitical neo-colonialism, disguised as business strategies, especially those whose nature is co-optation (Barley 2010; Fleming and Spicer 2014). This expansion follows the (unnatural) trend shown by markets - that of extrapolation of their natural limits, characterised by the commerce of material goods, imposing power over the other spheres of life - be they appropriate for commercialisation or not (Streeck 2016). In this regard, the main aim of this paper is to present evidence of the undetermined expansion of Polanyi's fictitious commodities in the Brazilian context, based on an analysis of the country's nuclear power sector. 
The sensitive characteristics of Brazil's nuclear power generation sector, as well as the history and peculiarities its nuclear policy constitution, allows for a clear outlining of the process of marketification of social agendas, emphasizing the relevance of the study (Brandão 2020; Kuramoto and Appoloni 2002). I stress, in advance, Eletronuclear's shareholding structure, composed of both private capital and state capital (majority) (Eletrobrás Eletronuclear 2012), suggesting broad governmental interference, including the favouring of marketification processes (Brandão 2020). In this sense, broad emphasis is given to the processes of marketification of social agendas through an empirical investigation conducted in the nuclear energy sector in Brazil, characterized by the intense action of activists and social movements. I have decided to engage with the decolonial option, mainly to deal with geo-epistemic and temporal frailties, as identified by Polanyi (Mignolo 2011, 2014; Porto-Gonçalves 2012). Norman Fairclough's critical discourse analysis (CDA) also contributed to the theoretical-analytical perspective which guided this paper.

\section{The works of Karl Polanyi: contributions and geo-epistemic criticism}

The life and academic trajectory of Karl Polanyi were closely interwoven with the path of resistance against the concept of the self-regulated markets and against the idea of a society essentially composed of (and based on) the market. Despite born in Vienna, Austria, Polanyi never agreed with the lines of thought of the Austrian economic school led by Ludwig von Mises and his disciple Friedrich Hayek at the time (Subirats 2014). However, the end of the market society does not mean the demise of markets (Levitt 2013). The most important aspect, however, is not the presence or absence of markets, given that their presence is certain, but rather their central position within society, and the actions based on economic self-regulation that result from it. Currently, the idea of a minimum influence of the State on the economy still survives, even after the Wall Street economic crisis, in which the 'hand of the State' was essential for the survival of many organisations. This situation led many multinational companies, like General Motors, to obtain government bailouts as the only alternative to stay afloat (Congleton 2009) - an idea which goes against the acclaimed neoliberal project (Harvey 2005, 2007). The same happened in 2020, as many companies were hit hard by the crisis instituted by COVID-19 pandemic (Nunes 2020).

It is valid, therefore, to infer that Polanyi did not defend a governance and regulation model with the State at its centre. His view was that society is the best qualified and most legitimate player to exercise the role of market regulator, since the State, as is the case nowadays, operated in favour of a hegemony - a viewpoint which agrees with the views held by Gramsci (Burawoy 2003), and which is coherent with the current political problems that Brazil is facing. This sheds light on the reason why Polanyi was so insistent regarding 'the reality of society. This is the reason why I refer to his 'society' as an 'active society.' From this perspective, based on the concept of 'active society', Polanyi replaced the movement of 'the society itself' by 'the society for itself', while keeping the same logic between the classes, namely from 'the class itself' to 'the class for itself' (Burawoy 2003). 
However, due to the author's Eurocentric perspective, many other peculiarities have not been taken into account in the theorisation process, such as his lack of awareness of the fact that under-socialised and oppressed communities, silenced by the subordination coming from peripheral and semi-peripheral regions (Dabashi 2015; Spivak 2010), would be unable to operate the expected social turnaround. In this regard, the oppressed and those made invisible grant their representation to the more favoured segment of society, which does not always happen entirely. Therefore, despite the undeniable contributions that Polanyi made to different fields of knowledge, the Eurocentric bias within his theory remains. In these terms, according to Mignolo (2014), any attempt to dewesternise and decolonise the social sciences (and society itself) based on a Euro-American bias, is nothing more than a rewesternisation that maintains the originality of the locus of announcement, despite a new clothing. Therefore, there are two aspects that warrant attention: (i) the need for a geographical and temporal adaptation of the theorisation, as proposed by Polanyi; and (ii) based on this adaptation, a better understanding of the relations among societies, markets, states and other players in peripheral and semi-peripheral contexts.

The first point mentioned is, in essence, a positioning problem, regarding the geography of knowledge through which Polanyi theorises, and also the temporality of such knowledge, as it is worth '[...] remembering that Karl Polanyi observed a society going through transformations different from those faced today' (Vadell and Carvalho 2014: 85). No matter how much effort the author made, the Eurocentric viewpoint blocks horizontal dialogue with other viewpoints and other worlds, due to the colonialist perspective that is firmly ingrained in Eurocentric thought (Grosfoguel 2008). A good example of this can be seen in the passage where Polanyi argues that one of the first urban markets (possibly even the first) was the Agora of Athens (Levitt 2013), hence disregarding the Chinese, the Arabs, the Moors and the whole of the Orient, basing himself on this geo-historical viewpoint (Haesbaert and Porto-Gonçalves 2006).

Karl Polanyi developed a sharp criticism of liberalism, using an argument based on historical reports of societies which, in spite of actually practicing commerce (or possibly barter), did not get tied up in the shackles of market forces. Even though his argument criticised the market concept based on the economy, the fact is that his theorisation was well aligned to the central economic discourse when it mentions that its central elements supply and make demands (Levitt 2013), it failed to consider other actors within these processes (Fligstein 2002; Ramos 1981). The progress in other market possibilities, such as the removal of submission to the 'non-market' through accepting the relevance of actors who were often obliterated by the geopolitics of knowledge (such as the State, government, the media, the legislative branch, NGOs, activists and others) and the resulting de-celebration of the neoliberal free market (Faria and Abdalla 2014), can help to fill in this gap. Such advances create possibilities for more pluralised and more inclusive theoretical constructions, which would allow dialogue between the Polanyian viewpoint with peripheral and semi-peripheral regions to occur.

With regard to 'society' in his theory, it is important to point out that this concept is Eurocentric in origin, by nature (Carmona 2008; Mignolo 2014; Nogueira 2003). Karl 
Polanyi did not escape from this logic, keeping his arguments supported by this conceptual perspective. In his opinion, capitalist countries were permeated by a permanent relationship of conflict between (free) market and society within themselves (Polanyi 2012 [1945]). The view of society to which he makes reference is very different from the agglomerations and under-socialised communities that were identified in historically subordinate regions, accustomed to not having a say, and that often are co-opted by the weight of hegemony. This process of becoming socially invisible is not envisaged by those who look at the phenomenon from above and from outside (Faria and Abdalla 2014). Based on his strong (and legitimate) concern in opposing the market society model, Polanyi brings back concepts and examples of societies that are largely disconnected from contemporary market practices, as well as considering elements such as politics and market sociology (Fligstein 2002). In spite of this, he does recognise such demands, and proposes that there is more to be explored in terms of these issues, thus leaving important gaps to be addressed (see, for instance, Levitt 2013).

\section{Neoliberalism, Fictitious Commodities, and other problems}

Among the different contributions made by Karl Polanyi, highlight is warranted, apart from fictitious commodities, of the idea of double market movement. The theorisation proposes that the quest for market independence suggests a movement that is harmful to society, which has been called the movement of markets. This 'movement' causes a process of tensions, which if exaggerated, can lead to social disintegration. The 'counter-movement' can be illustrated by the model of a machine of opposite reaction, working towards social self-protection, seeking the preservation of the human species and of nature, mobilised by the oppressed to stem the progress made by the market movement (Fiori 2000; Polanyi 2012 [1945]). Even though one can defend the idea that the neoliberal market is a problem for all types of societies, a society-market model could seem incomplete, as a market is permeated by society and vice versa (Fligstein and Dauter 2007; Fligstein and Habinek 2014), thereby making it unfeasible to operate these elements as mere forces in opposition. Under the viewpoint of 'social turnaround,' Polanyi (2012 [1945]) did not foresee the actions of organisations, institutions and other social players as possible opponents (or allies) of neoliberalism and its social consequences. In addition, the theorisation of the relationship between market and society, without defining the problem of its Eurocentric bias and the corresponding demand for viewpoints that do not neglect its locus of announcement, leaves a demand for major gaps to be addressed.

According to Burawoy (2003), the relationship between society and the market is not necessarily a battle of the gods, between good and evil, as argued by Karl Polanyi. The author emphasises the difficulty of a less euphoric recognition with regard to the social role, as advocated by Gramsci. Based on the Gramscian view and indirectly backed up by other authors (e.g. Barley 2010; Fairclough 1992; Nye 2005), civil society can become an instrument for domination used by the State, directed to act in favour of hegemony, exercising a kind of back-to-front countermovement. In these terms, the intended construction of a 
civilised society seems to be 'necessary' to make the contradictions of capitalism feasible, at the expense of communities, which could possibly oppose this combination of transformations as enforced by 'modernity'.

Despite the adoption of a mask of benevolence, mainly sustained by liberal ideas (Harvey 2005, 2007), the fact is that the neoliberal model advanced thanks to militarisation, which started mainly during the Cold War, through policies of deterrence. In the United States, history has shown that at the start of each new era, new reasons (or excuses) are used to back up processes of militarisation, intensification of hard power (Nye 2005), and imposition of globalising neoliberal agendas, through the use of force, as in the case of the 'war against terrorism,' which started with the terrorist attacks on 11 September 2001 (Harvey 2005). Apart from militarisation, another point that stands out within neoliberalism is that of financialisation. After money became a commodity in itself (Polanyi 2012 [1945]), organisations were able to trade it freely, through the deregulation of markets, speculation, fraud, predatory practices, and all kinds of 'strategies' [sic] (Harvey 2007; Lima 2020). Financialisation allows ' [...] paper riches to multiply, with relative independence from the addition of value of productive assets, real variables [...]' (Braga 2009: 96), thereby reinforcing the fictitious nature of the marketification of money, which can be seen in the financial collapse of companies such as Enron, Parmalat, Xerox, and many others.

In addition, the neoliberal project has led to uncontrolled growth of certain regions, around the marketification of labour. The inability of States to establish new job opportunities has favoured migration, and as a result, the agglomeration of people in and around market-oriented cities (or regions) (Abdalla 2014; Abdalla and Faria 2019; Davis 2004). The result of this process was the expansion of poverty in the cities, from the expulsion of poor people from downtown, pushing them to peripheral neighbourhoods, giving rise to the spaces of urbanisation once property prices became prohibitive (Harvey 2006, 2012). This mechanism started from the logic of Margaret Thatcher, reflected in the significant proliferation of slums and shantytowns in the world (Davis 2004). In this context of marginalisation, several alternative social forms emerge, thus filling in the void left by the State (Harvey 2007). Society at large, based on the fallacious promise of generation of income, creation of jobs and local development, now suffers from the expansion of asymmetries, characterized by privileges for large corporations, which grow ever-larger following an imperialist expansion model (Santos 2008).

Migratory processes, motivated by the marketification of labour, favour the growing marketification of land, materialised by the intense real estate speculation that has occurred in cities, resulting in problematic processes of densification of the population, illegal land occupancy, and gentrification (Abdalla and Faria 2019; Andersson and Turner 2014; Zheng and Kahn 2013).

When liberalism promoted land, labour and money, giving them the status of commodities, this caused at least two major problems: (i) the need for contractual and legal regulation of property rights; and (ii) the analogous possibility that several other (fictitious) elements would become commodities. This will be explored in greater depth in 
the sixth section of this paper. Harvey (2007) illustrated the first case by giving the example of the excessive legalism which is now present in US society, where everything converges to market rules, and that needs to be contractually and legally decided, as the right to property can be used for everything that is marketified. By analogy, several elements have become commodities, including the right to pollute and the resulting carbon market (Porto-Gonçalves 2012); the marketification of social agendas (Silva and Abdalla 2020); the marketification of education of those differently abled, in preparation for a bespoke 'labour market' (Lima and Mafra 2014), among other examples. It is no coincidence that there are people defending the view that 'we live in the Market Age' and that in it, everything can be obtained: commodities, jobs; even wives (Lie 1997). From this point of view, the marketification of social agendas is registered, especially in sensitive sectors, such as nuclear energy. In the next section, I present a brief overview of the Brazilian nuclear policy to support the debate proposed in this article.

\section{A brief overview of the Brazilian Nuclear Policy}

Although nuclear technology is aimed at civilian use and for peaceful purposes, its genesis is strongly related to the military field (Kuramoto and Appoloni 2002). For developing countries like Brazil, it is almost impossible to trace the conception of a new technology to its origins. The case of nuclear energy can be treated as an exception, since Brazilian scientists (whose majority were trained at least partly at foreign institutions) were nevertheless able to actively follow each step of this technology's development (Camargo 2006). To a great extent, this achievement was due to Admiral Álvaro Alberto da Motta e Silva, considered the forerunner and main articulator of national (and nationalist) policy for the nuclear sector in Brazil, in addition to being responsible for the implementation of the Brazilian Nuclear Program (BNP) (Brandão 2020; Camargo 2006). In spite of its early beginning, the BNP trajectory was (and is) far from a linear development (Andrade 2006). Several political and geopolitical events have caused the program to follow a tortuous path, marked by both positive and negative episodes.

The first Brazilian nuclear agreement (1945) came about through US exploratory interests and provided for the export of radioactive material to the United States. It is worth mentioning the so-called Baruch Plan, developed by Bernard Baruch and institutionalised by the US in 1946. The plan was in reality a US expropriation attempt, by proposing to internationalise all the uranium and thorium in the world, attributing the possession of this material to the UN Atomic Energy Commission of the UN, indirectly controlled by the Americans themselves (Camargo 2006; Goldemberg, Alvim and Mafra 2018).

The central argument foresaw the redress of 'an injustice of nature,' since countries that held dominance over nuclear technology (at that time, only the US) could not meet all demand for uranium domestically. The Baruch Plan camouflaged the intention of blocking nuclear development in other nations, creating strong resistance from the USSR, aggravating the ideals of the Cold War (Gerber 1982). Admiral Álvaro Alberto, through a counter peripheral movement (as Karl Polanyi expected), rejected the disrespect for na- 
tional sovereignty and the attempt to make the country a mere warehouse of U.S. minerals (Camargo 2006; de Sá 2015). The episode was only one of many imperialist and neo-colonialist attempts and actions imposed in different ways on those who wished to engage in the development of nuclear technology.

Admiral Álvaro Alberto's nationalistic position, as well as the work performed by the Brazilian Navy, allowed important advances between 1951 and 1963 (Herz, Dawood and Lage 2018). It is worth mentioning the creation of the National Research Council in 1951, (now the National Council for Scientific and Technological Development (CNPq in Portuguese)), originally strongly oriented to nuclear development (Jesus 2012). Another important milestone was the creation of the National Nuclear Energy Commission (CNEN in Portuguese) in 1956, which became an important player, not only for internal governance, but also for international politics (Andrade 2006), since in this sector's internal and external issues are inseparable from one another (Herz and Lage 2013).

In 1979, during the Brazilian military regime, under a logic of epistemic disobedience (Mignolo 2009), the so-called 'autonomous' or 'parallel' nuclear program was instituted, with developmental, autonomy and sovereignty purposes (Jesus 2012; Šubrtová and Terem 2018). The program, which operated secretly for years, initiated the construction of a nuclear powered submarine and was responsible for the creation of a unique uranium enrichment technology in the world (Duarte 2016; Šubrtová and Terem 2018). With the end of the Brazilian military regime, the 'parallel' nuclear program was integrated into the civilian program. An era of strong orientation towards the peaceful use of nuclear energy began to take place, materialised especially by the text of the 1988 Federal Constitution; the agreement with Argentina (currently quadripartite); and the creation of the ABACC (Brazilian-Argentine Agency for Accounting and Control of Nuclear Materials), besides the signing of several international non-proliferation treaties (Herz and Lage 2013; Goldemberg, Alvim and Mafra 2018).

Brazil played an important role in global nuclear policy during the presidential administrations led by the Workers' Party (2003-2016), both nationally and internationally. Former Presidents Luiz Inácio Lula da Silva and Dilma Rousseff, in addition to promoting substantial advances that entailed the revitalization of large projects (such as the resumption of the construction of the Angra III nuclear power plant), advocated the central role of the State in promoting national development (Herz et al 2018), in addition to the search for decolonization processes. The subsequent years have been marked by the stagnation of the sector, aggravated by the COVID-19 pandemic, starting in 2020 (and as of this writing, still in full swing).

\section{Epistemic and methodological path}

In an attempt to fill possible gaps shown in Polanyi's work, I decided to adopt the decolonial epistemic perspective (Grosfoguel 2008; Mignolo 2011, 2014; Porto-Gonçalves 2012) together with the theoretical and methodological baggage of critical discourse analysis (CDA) (Fairclough 1992, 2003), as a way of dealing with the multipolar and pluriversal 
character present not only in the chosen locus of knowledge, but also in the rest of the world. This choice was based on the need to seek decolonised viewpoints to deal with the rethinking of Polanyi's theorisation, yet without losing sight of the verticalisation of the dialogue between global North and South (Grosfoguel 2008).

This paper is part of a research project, meaning that the database is much larger than the one used here. The data were collected through in-depth interviews during 2014. All in all, 21 interviews were carried out, recorded and transcribed, based on a semi-structured outline, involving 20 people from the different parties and organisations involved in the Brazilian nuclear policy. Together, the interviews produced roughly 19 hours of recorded material, and a document with over 370 pages of transcription. The interruption of the data collection process was based on two criteria: (i) saturation - to the extent that no new information arose with new interviews, along with the convergence of the information as obtained (Fontanella and Magdaleno Júnior 2012); and (ii) my (in)ability to analyse excessively large volumes of qualitative data (Fairclough 1992; Gaskell 2015). The details of the interviewees are shown in Table 1. The company Eletronuclear appears as the main aim of the discussion, for it is the only generator of nuclear energy in Brazil, with two currently active plants and a third under construction. Thus, any mention of 'company' refers to Eletronuclear.

The analytic process was guided by the theoretical-methodological complex known as critical discourse analysis (CDA), which is an important way of seeing, understanding and (re)assigning meaning to social phenomena. In this regard, much more than just another proposed methodological path, CDA, through its robust and trans-disciplinary theoretical apparatus, can be defined based on a relevant onto-epistemological perspective

Table 1 - List of Interviewees

\begin{tabular}{lllll}
\hline Code & Player & \multicolumn{1}{c}{ Organisation } & $\begin{array}{c}\text { Experience within the } \\
\text { nuclear segment (years) }\end{array}$ & Academic Title \\
\hline I1 & Regulator & $\begin{array}{l}\text { National Nuclear Energy } \\
\text { Committee (CNEN) }\end{array}$ & 30 & Doctorate \\
\hline I4 & $\begin{array}{l}\text { Social } \\
\text { Representative }\end{array}$ & $\begin{array}{l}\text { Angra dos Reis Society } \\
\text { for Ecological Protection }\end{array}$ & 20 & $\begin{array}{l}\text { Incomplete } \\
\text { undergraduate course }\end{array}$ \\
\hline I8 & Regulator & $\begin{array}{l}\text { National Nuclear Energy } \\
\text { Commission (CNEN) }\end{array}$ & 38 & Doctorate \\
\hline I10 & Legislator & $\begin{array}{l}\text { Angra dos Reis City } \\
\text { Council }\end{array}$ & 12 & Technician \\
\hline I13 & Regulator & $\begin{array}{l}\text { National Nuclear Energy } \\
\text { Committee (CNEN) }\end{array}$ & 26 & Doctorate \\
\hline I15 & Company & Eletronuclear & 36 & Specialisation \\
\hline I16 & Company & Eletronuclear & 34 & High School \\
\hline I18 & Company & Eletronuclear & 35 & Doctorate \\
\hline
\end{tabular}

Source: Created by the author 
(Fairclough 1992, 2003; Mafra and Lobato 2017; Silva and Gonçalves 2017). The 'criticism' which underlies the 'analytic' characteristic, with regard to the discourses here considered, is made evident by the emancipatory aspect of the proposal. The emancipation, first and foremost, seeks to denaturalise meta-discursive beliefs, as firmly rooted in society as a means of domination, and then unveils and promotes the de-articulation of such structures, and the resulting social change (Fairclough 1992; Abdalla and Altaf 2018).

In the analytical path, I have tried to organise the data collected in a way that synthesised the information most relevant to this work. In the development of the CDA, I followed the three-dimensional model as proposed by Norman Fairclough (Fairclough, 1992). In addition, as analytical categories, I used a representational meaning, through the categories of 'interdiscoursability' and 'representations', and also an identificational meaning to account for identity, by the 'appraisal' category. After carrying out the CDA, I organised the analyses according to the underlying structure specified below, to best present the findings to readers. Figure 1, based on Abdalla and Altaf (2018), sums up the methodological path of this paper.

Figure 1 - Analytical Path of the Paper

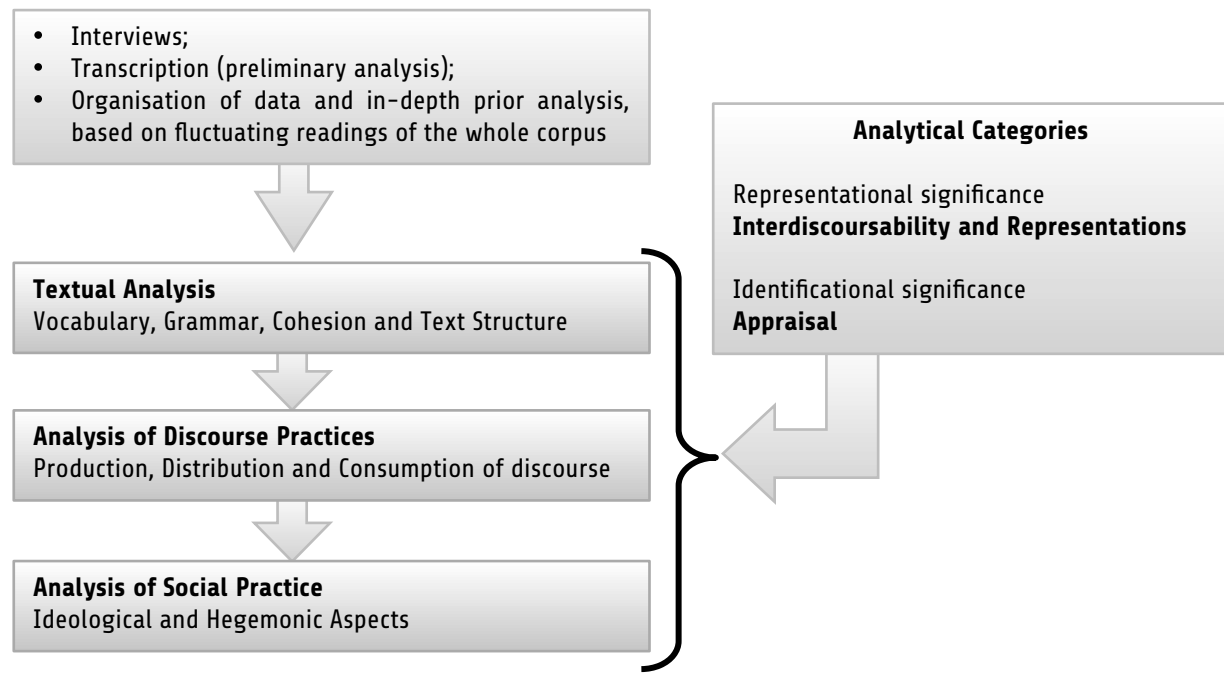

Source: Created by the author, based on Abdalla and Altaf (2018) and Fairclough (1992, 2003)

\section{The Brazilian Nuclear Energy Segment and its Fictitious Commodities}

The energy segment, as a whole, causes a host of social and environmental impacts. However, the context of nuclear energy generation has more sensitive characteristics, mainly as this has reached ' [...] the public, through a major incident, extremely negative, which was the bomb' (I13, 2014, emphasis added). Associated with these terrible events, that are not directly linked to energy production, I can mention three major accidents in the nuclear energy segment which have fuelled the growth of social movements against this technol- 
ogy. These read (i) Three Mile Island (United States, 1979); (ii) Chernobyl (former Soviet Union, 1986) and (iii) Fukushima Daiichi (Japan, 2011). Brazil has also had the most serious radiological accident in the whole world. This is not linked to energy generation, but, as in the case of the bombs, is often regarded generally as same thing. Based on these events, mentions of a 'nuclear' dimension are popularly associated with disasters in general. Apart from the risks inherent to nuclear generation, and the treatment that is given to nuclear waste, nuclear energy units also cause other types of social impacts, like any large business, including haphazard population densification. These risks and impacts are normally quantified and mitigated in an 'Environmental Impact Study' (EIA in Portuguese) and a related 'Environmental Impact Report' (RIMA in Portuguese). These documents are at the heart of Brazilian governmental negotiations, and define how much (and how a company must pay society to address such impacts, through 'Environmental Compensatory Measures' (Medidas Compensatórias Ambientais in Portuguese), in what amounts to a clear case of marketification of risks and impacts (Abdalla 2014).

\section{Risks and social demands: The context of compensation}

Throughout the whole process of negotiation between Eletronuclear and society, in addition to legal demands made naturally because of the socioenvironmental risks and impacts inherent to the nuclear power business, there was also an intensification of the efforts of social players to stress problems and as a result demand reparation. These representational discourse actions are here called 'reinforcement', and can be observed in the excerpts shown in Table 2, which are samples of the comments of a company executive, a city councillor, and an environmental activist.

Textual analysis of the fragment of I15 (2014) shows an attempt to convince through discourse, which is rebutted both by the cohesion of the text and its structure. The construction of arguments with an ironic question, followed by an apparently intuitive answer, based on common sense, shows a rhetoric that is well established and well-constructed, as a type of discourse to be distributed and consumed by the masses, on a large scale, while keeping the status quo of company empowerment. The rhetorical scheme is conclusive, in

Table 2 - Chart with Reinforcement of Socioenvironmental Risks and Impacts

I15 Have we created problems for the region? Look [...] [...] there is no way in which a human being can move on the planet without creating problems. Living is dangerous!

What is the immediate risk, and what is the risk in the long term? We don't even know if it exists, it is[...], naturally some leak that[...], that can bring problems to families after a few years; we don't know if [...]. Angra has a high rate of cancer, right?!

Positive things are individualised, while negative ones are socialised! Disgrace is always socialised! Excuse me for framing it like this! 
terms of showing that 'living is dangerous!' in an attempt to naturalise any kind of risk or impact produced by the company. The certainty imparted by the words of I15 (2014) can be categorised as an attribution of identificational meaning, through evaluation, as it is embedded with presumptions and judgements of value.

On analysing the fragment produced by I10 (2014), apart from the attempt to establish a rhetorical scheme and the adoption of identificational meanings through appraisal, as in the case of I15 (2014), it is possible to note some issues regarding the vocabulary used, suggesting 'leak,' rather than any other word, as a supposed element of risk 'to families.' The use of the word 'families' and not 'citizens' or even 'residents,' gives the discourse a somewhat more dramatic tone, which reinforces and amplifies the potential socioenvironmental risks and impacts produced by the company. The city councillor ends this excerpt with a question in an affirmative tone, which, using a scheme of cohesion, tries to blame Eletronuclear for cases of cancer incidence observed in the municipality of Angra dos Reis. Even though there are some studies that identify a normal profile of cancer deaths in the city (Lassance et al 2008), the councillor's discourse production, making statements and forming opinions, may be dangerously distributed, consumed, and also assumed to be the truth, acting as an expansive mechanism to convince and also for the marketification of social agendas. By indirectly assigning responsibility for a hypothetical rise in cancer cases in the municipality, the city councillor opens the gates for ideological battles, resulting in negotiations regarding payment of compensation, which will be used to promote the perpetuation of whoever is in power, keep the common citizen largely detached from the real problems. Different from the 'active society' as proposed by Polanyi, the peripheral society exercises silence as a condition for its subordinate position, lacking anyone who can truthfully represent this group, due to its condition as a silenced group (Spivak 2010).

On mentioning the benefits of Eletronuclear, distributed to a select part of society, environmentalist I4 (2014) also made use of textual structure and cohesion in favour of its intentionality. He made use of the term 'positive thing' to refer to actions of the company that benefit a few individuals, while referring to 'disgrace,' which could be attributed to all people. On using the term 'disgrace' rather than 'negative thing', I4 (2014) tried to add weight to the problem, even apologising for his/her utterance at the end of the referred statement. It is also possible to see some elements of interdiscursivity, especially when I4 (2014) alluded, implicitly as 'disgrace', to the major nuclear accidents, making use of discourses employed in other contexts and other episodes, as if these events could be transposed to the daily Brazilian routine.

The excerpts highlighted show aspects of representational and identificational meaning of discourse, in which texts complement and overlap each other, sometimes being intensified and, other times, mitigated through antagonistic aims, based on judgements and presumptions regarding value. In addition, social players are represented, and also represent, clear ideological positions, either in favour or against the nuclear segment (Fairclough 2003). 


\section{Risk versus Return: The 'Gold Mine' paradox}

If, on the one hand, nuclear energy generation brings a plethora of risks and socioenvironmental impacts, as alleged by civil society representatives and 'interested' institutions, on the other hand, there is an apparent disregard of this condition, superseded by the marketification of these agendas. This makes the relationship interesting yet paradoxical. To a certain extent, this condition seems to be somewhat desired, especially by institutions, so that there are reasons for the rewards to be negotiated. In Table 3, I present some excerpts that reinforce this statement.

An analysis of the fragment produced by I8 (2014) shows the appropriation of the discourse based on socioenvironmental safety by a government authority, reproduced in a way as to hammer out a deal for receipt of financial compensation. The structure of the text leads to the conclusion, based on the alleged risk, that 'then we also have to receive something.' Yet, in practice, this neither eliminates nor minimises the social problems that may emerge from this, albeit it could somewhat soothe the endless demand for resources. By mentioning that 'everybody wants something', the representative of the segment shows dissatisfaction with this model, which mixes the marketification of social agendas with the opportunism from the parties involved - something unthinkable based on Polanyi's view - still somehow predicted through the marketification of money, labour and land (Polanyi 2012 [1945]). The judgement expressed within the appraisal process indicates the presence of the analytical category of identificational significance.

The overlap of discourses, especially by the executive branch, shows the strong intention of perpetuation of power by hegemonic institutions. This situation can be seen in the comment by I1 (2014), showing an apparent situation of neglect, by the governmental authority, of real risks and impacts. Curiously, on reproducing the mayor's words, I1 (2014) used the word 'problem' to refer to the possible amount of financial compensation, in an allusion to the main aim of the government authority - which appears to steer well clear of social well-being. The conclusion reached by I1 (2014), followed by the fragment of I15 (2014), shows a significance that is interesting for Eletronuclear. Both for a company representative and for a representative of the inspection body, society and some institutions have been taking quick advantage of the frailty of the segment, to demand greater and greater financial compensation. This is made quite clear when I1 (2014) refers to the

Table 3 - Risk versus Return

The nuclear plants give money to the municipal government [...] [...] then he (the mayor) said: 'the
lorry, when taking fuel (uranium) to the nuclear power plant, passes here, along our road, meaning
that we should also receive something, as we run risks' [...] [...] everybody wants to (to receive
financial resources, depending on the risks supposedly involved)!

Source: Created by the author 
'goose that laid the golden eggs', referring to the best option, for institutions of the city to gather resources, without making any reference to social well-being. It is possible to stress the representational meaning through interdiscursivity, based on the appraisal processes, as highlighted by judgements already made, both by whoever produces the speeches (mayors) and by those who consume and distribute them (interviewees and society at large).

\section{Pseudo-Altruism and co-optation strategies}

On interviewing a company representative, responsible for the 'regional insertion department', there was no need for any kind of in-depth analysis to understand that the investments made in social responsibility are in fact the result of legal impositions, coming from the compensatory environmental measures, considered by I16 (2014) as 'conditioning':

'[...] Our programme for Social and Environmental Responsibility lies within the conditioning factors [...] [...] and so we have an obligation, and have a declaration of commitment, signed with the mayors. Angra, over R \$150 million; Paraty, over R \$40 million; Rio Claro, over R\$20 million.'

This funding by way of compensation, as originally required in counterpart for the risks and impacts inherent to the business, in a clear case of marketification of these elements, has also been promoting the marketification of social agendas, as in the adoption of the image of altruism, also bringing about processes of internal colonialism (Casanova, 2006). The excerpts identified in Table 4 show strategic details of pseudo-altruism and also the processes of co-optation used by the Company (Barley, 2010; Fleming and Spicer, 2014), strongly linked to their instrumental rationale (Ramos, 1981).

In the words of I16 (2014), it is possible to observe a condition of social effect, as obtained over time and apparently in different spheres. This condition, achieved progressively, is shown by the use of the word 'today' related to 'a very good relationship.' The textual structure and cohesion lead to the assumption that this condition is a result of the processes of marketification of agendas, negotiated with players, ranging from the legislative to

Table 4 - Pseudo-altruism and Co-optation Strategies

\footnotetext{
So today we have a very good relationship, a very good relationship indeed, with society, with I16 the executive and legislative branches, and also with all the institutions, and residents who belong to a certain community.
}

The company has always shown much concern, not only with employees but also with the surrounding society, so that the local populace may have better comfort and accept the nuclear power plant.

So, this means that we see Eletronuclear in normal situations, as being the party responsible for I13 the development of this good relationship with society, in the informative sense, and also in a move to gain confidence. 
the executive powers, to people who live in the area and also society at large. It is also important to take note of the identificational significance permeated by the positive appraisal of I16 (2014) with regard to the condition achieved. Apart from the clarity obtained in textual practice, it is also possible to envisage a strong intent to obtain the Company's hegemony. I argue that this consolidation attempt takes place through soft power, as laid out by Joseph Nye (Nye, 2005), based on an analysis of social practice (Fairclough 1992).

One important antecedent to the condition revealed by I16 (2014) can be seen in the comment of I18 (2014), in which he reports the concern shown by the Company in offering comfort not only to the employees, but also to the surrounding society, whose essential goal is that society 'accepts the nuclear power plant.' The context described at the start of this section shows just how troubled this segment is, also highlighting the existence of many resistance groups, mainly during the construction phase. This narrative reveals an ongoing concern regarding the social acceptance of the business, to make its presence within the municipality seem more natural. The process of exchange, or in other words, the marketification of the agendas (Silva and Abdalla 2020), can be seen at the end of this excerpt, when there is a negotiation of alleged comfort offered, in relation to the acceptance of the company, also showing clear signs of internal colonialism (Casanova 2006).

The process of naturalisation of impacts and risks, through the marketification of such elements, is seen by I13 (2014) as being a normal business action that reinforces the multiplication of Polanyi's fictitious commodities (Polanyi, 2012 [1945]) and the prevalence of instrumental rationality at the expense of substantive rationality (Ramos, 1981) within this institutional context. The 'good relationship with society' is achieved through the use of environmental compensatory measures, disguised as social responsibility, disclosed through a process of civilisatory education and internal coloniality (Casanova 2006; Mignolo 2011, 2014; Santos 2008); all to 'gain the confidence' of this player. Once again, textual analysis shows organisational astuteness, which can be complemented by discourse practice, on envisaging the production and the distribution of colonising speeches to maintain the hegemonic and ideological status quo, observed in, and based on, social practice. It is also possible to identify aspects of inter-discursivity in the discourse of the interviewees, as one can identify the intention of 'doing good' in exchange for the social acceptance of the business activity.

\section{Empowerment and silencing}

Both the strategies of co-optation used by the Company to promote greater acceptance by the various stakeholders and the strategies used by players from society to harness resources from reparations, have led to a situation of silencing of social agendas over time, as these have been publicly marketified on several occasions. These negotiations have also promoted an empowerment of the Company, to the extent that it operates in parallel with the municipal executive power. Table 5 contains excerpts that endorse such conclusions.

Historically, the resistance to the nuclear power segment is full of symbolism and significant events. However, as I6 (2014) reported, these events, especially within the Bra- 
zilian context, have diminished significantly. Not only I6 (2014), but many other interviewees reported this perception, which I also share. The questioning, which refers to the accident at Fukushima, is also conclusive, especially for its representational content, by suggesting the way in which activists, as social players, are classified in ideological terms. The reduction of production, distribution and consumption of discourse contrary to the nuclear segment was strengthened by the declarations made by powerful organisations, such as the recommendation of the expansion of the segment as proposed by the Intergovernmental Panel on Climate Change, due to the small volume of carbon emissions (IPCC 2014). Based on the historical logic used by social players to maximise their perception of risks and impacts, the nuclear disaster at Fukushima was indeed a great opportunity for some to attack the segment. However, it seems that the power of co-optation has been acting in such a way that even the member of the segment himself or herself shows surprise in light of the silencing of social agendas, negotiated at many instances in the past.

As a result of such actions, which have both co-opted and silenced social agendas through marketification, it is possible to highlight the significant empowerment of the Company, shown in the statements made by I16 (2014), with a certain degree of reservation, mainly when I16 (2014) mentions 'I don't know if I can say this.' I16 (2014) assigns the name 'governmental policies' to the compulsory investment in actions towards social and environmental reparation, which have conveniently been converted into social and environmental responsibility. By doing so, I16 (2014) signifies governmental policies as a means of exchange for negotiations with the legislative branch, with the executive branch and with society at large, especially in the immediate surroundings. It is necessary to emphasize that since Eletronuclear has mixed public and private ownership, with control exercised by the Brazilian government, it can be said that the public entity emulates the market, lobbying with the public sector itself. Thus, the private politics (Baron 2012; Baron, Neale and Rao 2016) in the form of these 'governmental policies', has allowed the company to implement a massified distribution process, with discourses based on naturalisation and acceptance, well consumed and reproduced by the local community, muting new demands, with these only arising at convenient moments - especially with the intention of obtaining financial privileges. The systematics have been naturalising sensitive relationships and ensuring the maintenance of the hegemonic status quo, in which the market is superimposed on society, as can be seen in Figure 2.

Table 5 - Empowerment and Silencing

I have already witnessed stronger protests [...] [...] but I don't see so many today. [...] This was not

16 an opportunity for these NGOs to get stronger, and this is why it happened [a reference to the Fukushima accident in 2011]! 


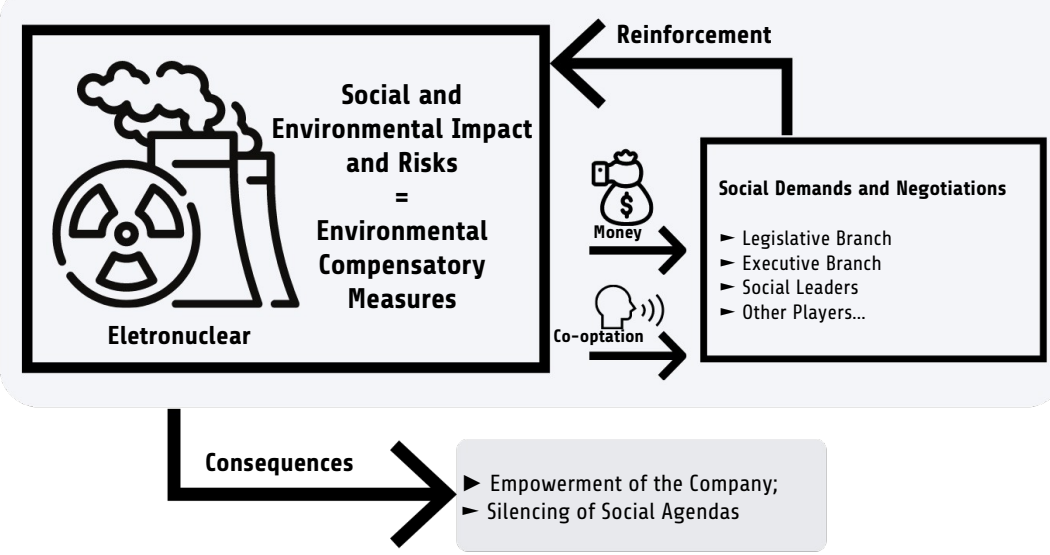

Source: Created by the author.

\section{Conclusions}

Karl Polanyis work shows dissatisfaction and disagreement with regard to the market society in a very clear way. His expectations regarding a social turnaround, pursued by an 'active society' at first sight does not seem feasible in peripheral and semi-peripheral societies. The reason therefor is mainly attributed to the history of coloniality, reinforced by the condition assigned to the subalternised societies of not having the right to exercise a voice. The main purpose of this work was to show the unlimited expansion of Polanyi's fictitious commodities in the Brazilian context, with emphasis on the marketification of social agendas, especially in the nuclear power segment.

It is possible to highlight at least two important contributions of this paper. The first is the temporal and geopolitical updating of the ideas raised by Polanyi with regard to the very concept of 'fictitious commodities', mainly through an engagement with the decolonial epistemic perspective. A second contribution is the definition of the mechanisms used by the nuclear power segment in Brazil, associated with the elites and the government, to de-articulate social and political agendas (through marketification). The parcel of society that consumes business discourses is co-opted by the apparent development that the business operation allegedly brings. Yet it shows itself to be largely unaware of the problems stemming from the multiplication of urban space; social reorganisation; and the resulting asymmetries produced in the process.

Social and environmental activism has been silenced by the powerful negotiation structure within the Company, due to its significant financial injection, which in many cases leads to the demise of social movements through the widespread supply of 'social benefits' in the form of 'corporate social responsibility.' The executive and legislative branches are also part of this process, favouring the act of co-optation, by promising to supply 'modernity', granting out tax breaks, allied to fears of social risks and all kinds 
of 'fictitious commodities' that unfortunately one could argue have become real. In this model, where the State acts together with the private sector, in the form of an autarky, emulating the market model, the transfer of resources between and within branches (for example, from the executive to the legislative), is commonplace. This demonstrates that the process of marketification does not take place in a governmental regulatory vacuum; on the contrary, it is mainly the product of the action of public power. When part of the government manages social misfortunes in benefit of its own image and agenda, one may argue that there is no doubt that unfortunately hegemony is 'winning the game.'

The collapse of capitalism, envisaged by authors such as Streeck (2014), especially through the extinction of Polanyi's fictitious commodities, seems to be giving rise to a new concept with countless new fictitious commodities, which have become increasingly more real, like the above-mentioned marketification of social agents. Here it is also worth mentioning the marketification of socioenvironmental risks and impacts resulting from the industrialization process which, as mentioned by Karl Polanyi, were not born to be marketified. Even so, in the nuclear power segment, they started to be fictitious commodities that were widely sought and traded by institutions, not necessarily exposed to such risks and impacts.

This logic benefits the elites at the expense of exposure of communities that have been rendered practically invisible and that are therefore unable to visualise the alleged Polanyian turnaround, as it is not being considered within the category of 'active societies.' While the uncertainty of extinction remains overhead, Karl Polanyi's fictitious commodities follow the capitalist market logic, thereby expanding the scope of social problems. These are, namely, (i) money - feeding the mechanisms of infinite accumulation and also the widening of social asymmetries (see Piketty 2014); (ii) labour - operating based on an intense logic of hyper-competition and installation of precariousness; and (iii) land - mobilised by an intense social migration, especially people looking for work. The latter has only worsened the problems of gentrification, especially in major cities of the globe. Finally, in spite of the efforts related to autonomy, the sector continues to reproduce internally the international mechanisms of coloniality.

\section{Notes}

1 In this case, the concept 'postmodern' is brought under a critical sense, in the light of the decolonial option, which disengages from these chronologies and epistemes constructed by eurocentrism.

\section{References}

Abdalla, M M. 2014. Repensando o Duplo Movimento Polanyiano a partir do Desenvolvimento de Estratégias Sociais: um olhar sobre o setor de energia nucleoelétrica à luz da opção decolonial. $\mathrm{PhD}$ Thesis, Fundação Getúlio Vargas (FGV-EBAPE), Brazil.

Abdalla, M M and J G and Altaf. 2018. 'Análise Crítica do Discurso em Administração e em Gestão: Sistematização de um Framework Metodológico.' Revista ADM.MADE 22 (2): 35-47. 
Abdalla, M M and A Faria. 2019. 'Local development versus neoliberal globalization project: reflecting on market-oriented cities.' Revista de Administração Pública 53 (1): 84-100.

Andersson, R and L M Turner. 2014. 'Segregation, gentrification, and residualisation: from public housing to market-driven housing allocation in inner city Stockholm. International Journal of Housing Policy 14 (1): 3-29.

Andrade, A M R de. 2006. A Opção Nuclear: 50 Anos Rumo à Autonomia. Rio de Janeiro: Museu de Astronomia e Ciências Afins, MAST : CNEN, Brazilian Ministério da Ciência e Tecnologia.

Arrighi, G. 1994. The Long Twentieth Century. London and New York: Verso.

Barley, S R. 2010. 'Building an Institutional Field to Corral a Government: A Case to Set an Agenda for Organization Studies.' Organization Studies 31 (6): 777-805.

Baron, D P. 2012. 'The Industrial Organization of Private Politics.' Quarterly Journal of Political Science 7 (2): 135-174.

Baron, D P, M Neale and H Rao. 2016. 'Extending Nonmarket Strategy: Political Economy and the Radical Flank Effect in Private Politics.' Strategy Science 1 (2): 105-126.

Braga, J C. 2009. 'Crise sistêmica da financeirização e a incerteza das mudanças.' Estudos Avançados 23 (65): 89-102.

Braga, C F G V and L V Braga. 2012. 'Desafios da energia no Brasil: panorama regulatório da produção e comercialização do biodiesel.' Cadernos EBAPE.BR 10 (3): 751-762.

Brandão, R V d. M. 2020. 'Ditadura, Política Nuclear e Interesses Empresariais: a participação da Siemens no acordo de cooperação nuclear Brasil-Alemanha.' Revista Continentes 9 (16): 124-155.

Burawoy, M. 2003. 'For a Sociological Marxism: The Complementary Convergence of Antonio Gramsci and Karl Polanyi.' Politics and Society 31 (2): 193-261.

Camargo, G. 2006. O Fogo dos Deuses: Uma História da Energia Nuclear - Pandora 600 a.C. - 1970. Rio de Janeiro: Contraponto.

Carmona, R G. 2008. 'Descentralização, sociedade civil e participação: tendências e desafios.' Revista Capital Científico 6 (1): 165-178.

Casanova, P G. 2006. 'Colonialismo Interno' (una redefinición). In A A Boron, J Amadeo and S González (eds.), 'La teoría marxista hoy: problemas y perspectivas.' Buenos Aires: Clacso, pp. 409434.

Congleton, R D. 2009. 'On the political economy of the financial crisis and bailout of 2008-2009' Public Choice 140 (3-4): 287-317.

Dabashi, H. 2015. Can Non-Europeans Think? London: Zed Books.

Dale, G. 2013. 'Duplos movimentos e forças pendulares: perspectivas polanyianas sobre a era neoliberal.' Otra Economía 7 (12): 26-44.

Davis, M. 2004. 'The Urbanization of Empire: megacities and the laws of chaos.' Social Text 22 (4): 9-15.

de Sá, A. 2015. 'Brazil’s Nuclear Submarine Program.' The Nonproliferation Review 22(1): 3-25.

Duarte, S de Q. 2016. 'Brazil and the nonproliferation regime: a historical perspective.' The Nonproliferation Review 23 (5-6): 545-558. 
Eletrobrás Eletronuclear. 2012. Relatório da Administração e de Responsabilidade Social 2012. At: $\quad<$ http://www.eletronuclear.gov.br/LinkClick.aspx?fileticket=VhOMis66HMQ\%3Dandtab\%0Aid=112> [Accessed on 15 May 2014].

Fairclough, N. 1992. Discourse and Social Change. Cambridge: Polity Press. 2003. Analysing Discourse: Textual Analysis for Social Research. Oxford: Routledge.

Faria, A and M M Abdalla. 2014a. 'Engajando com o Lado Mais Sombrio do Mercado e da Gestão.' Paper delivered at the XXXVIII Encontro Da ANPAD. Rio de Janeiro, Brazil, 13-14 September. 2014b. ‘O que é (estratégia de) não mercado?’ Organizações and Sociedade 21 (69): 315-333.

Fiori, J L. 2000. 'A propósito de uma 'Construção Interrompida.' Economia e Sociedade 14 (1): 1-19. Fleming, P and A Spicer. 2014. 'Power in Management and Organization Science.' The Academy of Management Annals 8 (1): 237-298.

Fligstein, N. 2002. The Architecture of Markets: An Economic Sociology of Twenty-First-Century Capitalist Societies. Princeton: Princeton University Press.

Fontanella, B J B and R Magdaleno Júnior. 2012. 'Saturação teórica em pesquisas qualitativas: contribuições psicanalíticas.' Psicologia Em Estudo 17 (1): 63-71.

Frerichs, S. 2013. 'From Credit to Crisis: Max Weber, Karl Polanyi, and the Other Side of the Coin.' Journal of Law and Society 40 (1): 7-26.

Gaskell, G. 2015. 'Entrevistas Individuais e Grupais.' In.: M W Bauer and G Gaskell (eds.), 'Pesquisa Qualitativa com Texto, Imagem e Som: Um Manual Prático.' 13rd ed. Petrópolis: Vozes, pp. 64-89.

Gerber, L G. 1982. 'The Baruch Plan and the Origins of the Cold War.' Diplomatic History 6 (4): 69-96.

Goldemberg, J, C F Alvim and O Y Mafra. 2018. 'The Denuclearization of Brazil and Argentina.' Journal for Peace and Nuclear Disarmament 1 (2): 383-403.

Grosfoguel, R. 2008. 'Para descolonizar os estudos de economia política e os estudos pós-coloniais: Transmodernidade, pensamento de fronteira e colonialidade global.' Revista Crítica de Ciências Sociais 80: 115-147.

Haesbaert, R and C W Porto-Gonçalves. 2006. A Nova Des-Ordem Mundial (2a). São Paulo: Editora UNESP.

Hart, K. 1986. 'Heads or Tails? Two Sides of the Coin.' Man 21 (4): 637-656.

Harvey, D. 2005. The New Imperialism. New York: Oxford University Press. 2006. 'Neo-liberalism as creative destruction.' Geografiska Annaler: Series B, Human Geography 88 (2): 145-158. 2007. A Brief History of Neoliberalism. New York: Oxford University Press. 2012. Rebel Cities: From the Right to the City to the Urban Revolution. London: Verso.

Herz, M, L Dawood and V C Lage. 2018. 'The Defense-Development Nexus: Brazilian Nuclear Policy under the Workers' Party Administrations.' Revista Brasileira de Politica Internacional 61 (1): $1-19$.

Herz, M and V C Lage. 2013. 'A Atual Política Nuclear Brasileira.' BRICS Policy Center 3 (58): 1-24. IPCC. 2014. Climate Change 2014: Mitigation of Climate Change Report. Geneva. 
Jesus, D S V de. 2012. 'Noites tropicais: o Brasil e a nova era da não proliferação e do desarmamento nucleares (2003-2010)'. Revista de Sociologia e Política 20 (43): 43-57.

Kischener, M A, M A Perondi, M A Monteiro, E M Batistela, R T Borges, and R Kischener. 2015. 'A Contribuição de Polanyi na Compreensão do Processo de Mercantilização da Sociedade Rural.' Revista de Desenvolvimento Econômico 17 (31): 206-217.

Kuramoto, R Y R and C R Appoloni. 2002. 'Uma Breve Hitória da Política Nuclear Brasileira.' Caderno Brasileiro de Ensino de Física 19 (3): 379-392.

Lassance, A, A S A Fonseca, L F Pinto, and D Soranz. 2008. Estudo Comparativo da Mortalidade por Câncer dos Municípios de Angra dos Reis e Cabo Frio no Período de 2001 a 2005. Rio de Janeiro.

Levitt, K P. 2013. From the Great Transformation to the Great Financialization: On Karl Polanyi and Other Essays. London: Zed Books.

Lie, J. 1997. 'Sociology of Markets.' Annual Review of Sociology 23 (1): 341-360.

Lima, M P de and F L N Mafra. 2014. 'Mercado Educacional e Mercado de Trabalho: a Qualificação de Pessoas com Deficiência sob Encomenda.' Paper delivered at the II Congresso Brasileiro de Estudos Organizacionais. Uberlândia, Brazil, 18-21 November.

Lima, R J D C. 2020. 'From 'Back in the race' to 'Push to pass': estratégias de lucro da PSA Peugeot-Citroën.' Civitas - Revista de Ciências Sociais 20 (1): 119-132.

Mafra, F L N and C B de P Lobato. 2017. 'A colonialidade no discurso corporativo da água da boa mesa' sob a ótica da Análise Crítica do Discurso. Paper delivered at the XLI Encontro Da ANPAD (XLI EnANPAD), 17. São Paulo, Brazil 1-4 October.

Mignolo, W D. 2009. 'Epistemic Disobedience, Independent Thought and Decolonial Freedom.' Theory, Culture and Society 26 (7-8): 159-181.

2011. 'The Darker Side of Western Modernity: Global Futures, Decolonial Options.' Durham: Duke University Press.

.2014. 'Spirit out of bounds returns to the East: The closing of the social sciences and the opening of independent thoughts.' Current Sociology 62 (4): 584-602.

Munck, R. 2004. 'Globalization, Labor and the 'Polanyi Problem.' Labor History 45 (3): 251-269.

Nogueira, M A. 2003. 'Sociedade civil, entre o político-estatal e o universo gerencial.' Revista Brasileira de Ciências Sociais 18 (52): 185-202.

Nunes, J. 2020. 'A pandemia de COVID-19: securitização, crise neoliberal e a vulnerabilização global.' Cadernos de Saúde Pública 36 (5): pp. 1-4.

Nye, J. S. 2005. Soft Power: The Means to Success in World Politics. New York: Public Affairs.

Piketty, T. 2014. Capital in the Twenty-First Century. Cambridge and London: The Belknap Press of Harvard University Press.

Polanyi, K. 2012. The Great Transformation: The Political and Economic Origins of Our Time. Boston: Amereon.

Porto-Gonçalves, C W. 2012. A Globalização da Natureza e a Natureza da Globalização. 3rd ed: Rio de Janeiro: C. Brasileira.

Ramos, A G. 1981. A Nova Ciência das Organizações: Uma Reconceituação da Riqueza das Nações. Rio de Janeiro: Fundação Getúlio Vargas. 
Santos, M. 2008. Por uma Outra Globalização: Do Pensamento Único à Consciência Universal. 15th ed. Rio de Janeiro: Editora Record.

Silva, A O and M M Abdalla. 2020. 'Desenvolvimento? Para quem? Relações estratégicas entre empresa e sociedade: o lado obscuro da privatização da Companhia Siderúrgica Nacional (CSN).' Revista Eletrônica de Administração 26 (1): 49-80.

Silva, E R da and C A Gonçalves. 2017. 'Possibilidades de incorporação da análise crítica do discurso de Norman Fairclough no estudo das organizações.' Cadernos EBAPE.BR 15 (1): 1-20.

Spivak, G C. 2010. 'Can the Subaltern Speak?' In R C Morris (ed), 'Can the Subaltern Speak? Reflections on the History of an Idea.' New York: Columbia University Press, pp. 21-78.

Streeck, W. 2016. How Will Capitalism End? Essays on a Failing System. London: Verso.

Subirats, J. 2014. 'Acerca del renovado interés por Karl Polanyi.' Cadernos EBAPE.BR 12 (2): 199-205.

Šubrtová, N and P Terem. 2018. 'Brazil's Nuclear Policy and its Rise on International Stag.' Acta Scientifica Academiae Ostroviensis 2 (12): 224-243.

Vadell, J A and P H N Carvalho. 2014. 'Neoliberalismo na América do Sul: a reinvenção por meio do estado.' Contexto Internacional 36 (1): 75-111.

Zheng, S and M E Kahn. 2013. 'Does Government Investment in Local Public Goods Spur Gentrification? Evidence from Beijing.' Real Estate Economics 41 (1): 1-28.

\section{Interviews}

Angra dos Reis City Council representative (I10). 2014. Interviewed by the author. 17 March.

Angra dos Reis Society for Ecological Protection representative (I4). 2014. Interviewed by the author. 18 February.

Company representative (I15). 2014. Interviewed by the author. 18 March.

Company representative (I16). 2014. Interviewed by the author. 20 March.

Company representative (I18). 2014. Interviewed by the author. 27 March.

National Nuclear Energy Commission representative (I1). 2014. Interviewed by the author. 7 January.

National Nuclear Energy Commission representative (I8). 2014. Interviewed by the author. 7 March.

National Nuclear Energy Commission representative (I13). 2014. Interviewed by the author. 20 March. 


\section{About the author}

Márcio Moutinho Abdalla is an Adjunct Professor of Strategic Management in the Department of Business and Public Management and Professor and Coordinator of the Professional Masters' Programme in Administration at the Fluminense Federal University (UFF), in Volta Redonda-Brazil. He holds a Ph.D. in Administration from the Brazilian School of Public and Business Administration (FGV/EBAPE) in Brazil. He was a member of the Scientific Committee of ANPAD's (National Association of Graduate Studies and Research in Administration) Strategy in Organizations area (2018-2020). He was editor-in-chief and founder of the Journal of Administration Society and Innovation (RASI) from 2015 to 2019. His research focuses on topics related to strategic management; non-market strategies; corporate political activity; decoloniality; transmodernity; and critical discourse analysis.

\section{Repensando os Produtos Fictícios de Polanyi com base no Segmento Nuclear Brasileiro}

Resumo: O objetivo deste trabalho é mostrar evidências da expansão indeterminada das mercadorias fictícias de Polanyi dentro do contexto nuclear brasileiro. É dada muita atenção à questão da mercantilização das agendas sociais. Os dados foram coletados através de entrevistas aprofundadas e o processo analítico foi orientado pela opção decolonial e pela análise crítica do discurso. Entre as conclusões, pode-se apontar a elaboração de uma estrutura que revela os mecanismos empregados pelo segmento nuclear brasileiro como forma de exercer o poder paralelo e silenciar as agendas sociais. As principais contribuições deste trabalho são a atualização temporal e geopolítica da tese de Polanyi e a definição dos mecanismos utilizados pela Eletronuclear e pelas instituições como forma de cooptação, naturalização e mercantilização das agendas sociais e políticas.

Palavras-chave: Karl Polanyi; commodities fictícias; nuclear; neoliberalismo; decolonialismo; análise do discurso crítico; agendas sociais.

Received on 13 October 2019 and approved for publication on 29 March 2021.

\section{(c) BY-NC} https://creativecommons.org/licenses/by-nc/4.0/ 